\title{
Computer Aided Model for Casting Aluminium Using Die-Casting
}

\author{
Pius Bamidele Mogaji ${ }^{1}$, Samuel Babatope Adejuyigbe ${ }^{2}$ and Olawale Mattew Tunde Bada ${ }^{2}$ \\ 1. Department of Mechanical Engineering, Federal University of Technology, Akure \\ 2. Department of Mechanical Engineering, Federal University of Agriculture, Abeokuta
}

Received: January 22, 2014 / Accepted: February 06, 2014 / Published: February 25, 2014.

\begin{abstract}
Computer aided casting of aluminum using die-casting was developed. A piston, which is an automobile part and very important in internal combination engine, was chosen for the research. Pistons are made of aluminum alloy. Models of the products were developed to aid the casting process. Mathematical models that show the dimensions of the casting were also developed. Since the project is about using computer to aid casting process, a program using visual basic (VB) Language was developed. The program was used to incorporate die-casting process into computer system. The written program was tested and the model of the casting product (piston) was displayed. The result shows that computer which is faster with accurate result can be used as an aid in the production of aluminum piston using die-casting process, for accurate planning in the manufacture of the product.
\end{abstract}

Key words: Computer aided, model, casting, aluminium, die casting.

\section{Introduction}

A piston is a component of reciprocating engines. It is the moving component that is contained by a cylinder and is made gas-tight by piston rings. In an engine, its purpose is to transfer force from expanding gas in the cylinder to the crank shaft via a piston rod [1]. Pistons are cast from aluminium alloy. For better strength and fatigue life, some racing piston may be forged instead. Early piston were of cast iron, but there were obvious benefits for engine balancing if a lighter alloy could be used [2]. However, the significance role played in the internal combustion engine has made its manufacturing to be done by die casting process [3]. Casting is a manufacturing process by which a liquid material is usually poured into mould, which contains a hollow cavity of the desired shape and then allowed to solidify [4]. Die casting is a metal casting process that is characterized by forcing molten metal under high

Corresponding author: Pius Bamidele Mogaji, doctor, research fields: computer aided engineering. E-mail: mogajipb@tut.ac.za,pbmogaji@yahoo.com. pressure into a mould cavity. The mould cavity is created using two hardened tool steel dies which have been machined into shape and work similarly to an injection mould during the process [5]. Most die castings are made from non-ferrous metals, especially zinc, copper, aluminium and magnesium based alloys. Depending on the type of metal being cast, a hot- or cold-chamber machine is used [6]. Manufacturing of parts using die casting is relatively simple, involving only four steps, which keeps the incremental cost per item low. It is especially suited for a large quantity of small to medium sized castings than any other casting process [5]. Die casting are characterized by a very good surface finish and dimensional consistency. There are two basic techniques of die casting [6] namely: Gravity Die Casting and Pressure Die Casting, hence, is been used for this study.

The area of foundry operations had been though too difficult to computerize. However, the advantages to be gained by the application of methods of computer-aided engineering (CAE) can no longer be ignored [7]. Plants 
that have made use of $\mathrm{CAD} / \mathrm{CAM}$ in foundry have, along with other benefits, found computer technology important in monitoring solidification temperature and thereby the quality of the casting $[8,9]$.

Computer aided design (CAD) is defined as any design activity that involves the effective use of the computer to create, modify, or document an engineering design. The need to program at each stage of manufacture is avoided by the use of standard form of data already stored in the computer by CAD [10]. computer aided manufacturing (CAM) is the use of computer system to plan, manage and control the operation of manufacturing plants through either direct or indirect computer interface with the plant production resources [11].

Computer-aided manufacturing (CAM), it include the use of digital computer to enhance the shop floor manufacturing process include monitoring and controlling of manufacturing equipment shop floor information system with automatic data gathering are part of a CAM system [10]. CAM, is a form of automation and control system that employ feedback, i.e., they use part output to control their input [12].

This study will help to produce an aluminium cast piston of good quality which is relatively cheap within a limited time, thereby eliminate the bottle neck of design parameters.

\section{Mathematical Model}

The task of constructing a mathematical model that can simulate the motion of liquid metal is done. This motion is governed by the principles of classical mechanics and thermodynamics for the conservation of mass, momentum and energy. These equations, along with the equations of state and the boundary conditions, determine the pressure, velocity and temperature distributions of the fluid. The design for engine piston was also done as shown below [13-15].

\section{Design for Engine Piston}

Thickness of the piston head or crown is $t_{\mathrm{H}}$ :

$$
\mathrm{t}_{\mathrm{H}}=\sqrt{\begin{array}{l}
3 p D 2 \\
16 \sigma t
\end{array}}
$$

where:

$\mathrm{t}=$ thickness of the piston;

$\mathrm{P}=$ maximum gas pressure;

$\mathrm{D}=$ cylinder bore;

$\sigma=$ permissible tensile stress $(50-90 \mathrm{Mpa}$ for $\mathrm{Al})$.

Width of piston top land is bi:

$$
\mathrm{bi}=1 \mathrm{t}_{\mathrm{H}} \text { to } 1.2 \mathrm{t}_{\mathrm{H}}
$$

Thickness of the groove is $t_{1}$ :

$$
\mathrm{t}_{1}=\mathrm{D} \sqrt{\begin{array}{l}
3 p w \\
t \sigma
\end{array}}
$$

where, $\omega$ is the angular velocity of piston.

Depth of the piston ring groove is $\mathrm{b}$ :

$$
\mathrm{b}=\mathrm{t}_{1}+0.4
$$

$\mathrm{l}_{\mathrm{i}}=$ length of the piston pin in the bush of small end = $0.45 \mathrm{D} ; \mathrm{P}_{\mathrm{b}} \mathrm{l}=$ Bearing pressure at the small end.

Axial thickness of the ring groove is $t_{2}$ :

$$
\mathrm{t}_{2}=0.7 \mathrm{t}_{1} \text { to } \mathrm{t}_{1}
$$

Length of the opening end of the piston is $1_{2}$ :

$$
1_{2}=1_{1}+0.51_{1}
$$

Maximum thickness of barrel is $t_{3}$ :

$$
\mathrm{t}_{3}=0.03 \mathrm{D}+4.5
$$

Piston wall thickness towards the opening end is $t_{4}$ :

$$
\mathrm{t}_{4}=0.25 \mathrm{t}_{3} \text { to } 0.35 \mathrm{t}_{3}
$$

Total length of the piston is $\mathrm{L}$ :

$\mathrm{L}=$ length of the skirt + length of the ring + Top land.

\section{Results and Discussion}

This section covers the running of the program that was written and its output Figs. 1-4. Having supplied the necessary data needed for the casting, there supposed to be an interface between the process (casting) and the computer system. In this case, an interface is developed (Fig. 1)

The values of the thickness of the piston head, (TH) was calculated by imputing the values of the maximum Gas pressure, cylinder diameter and the permissible stress (which range from 50-90 MPa). 


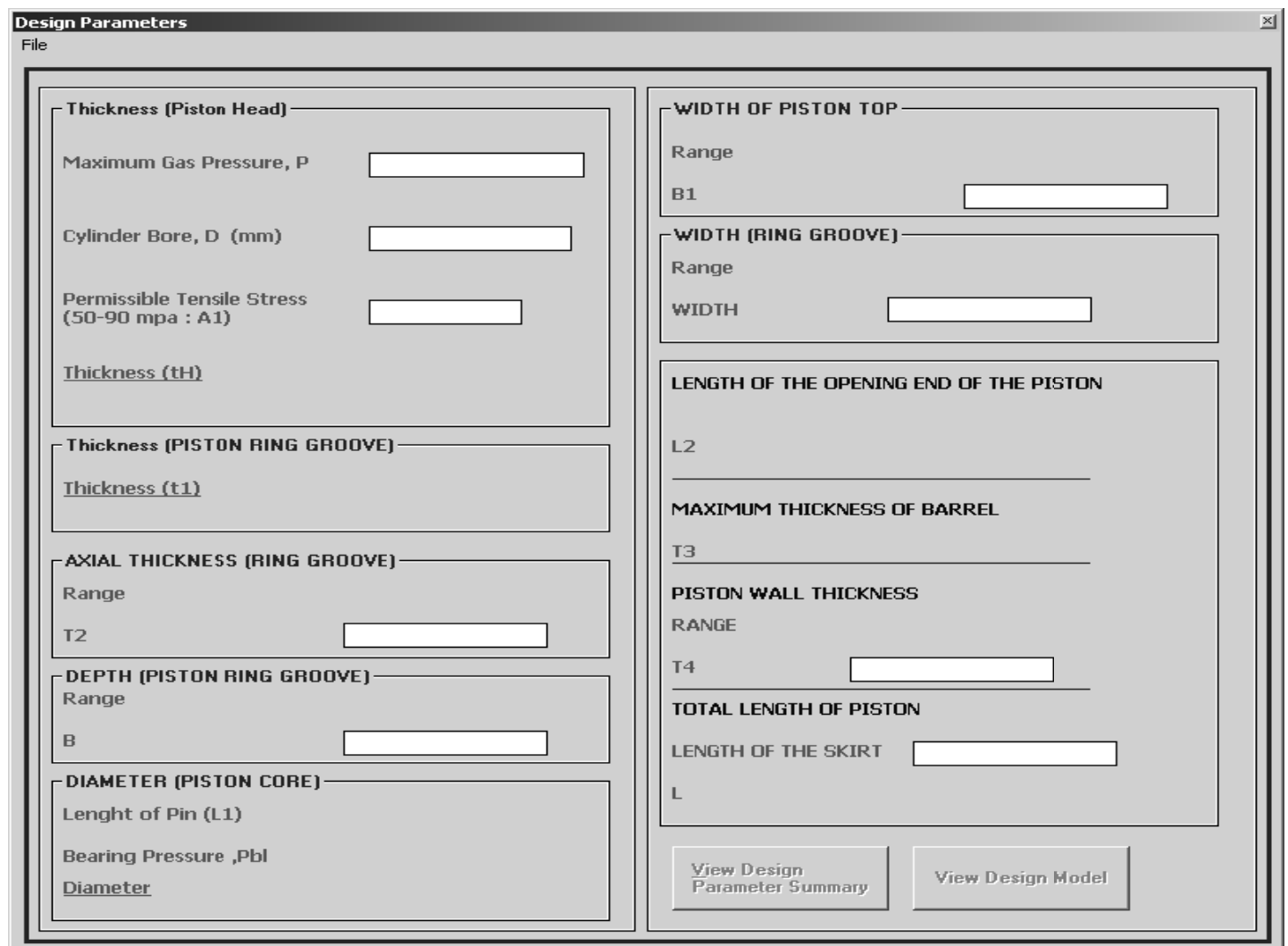

Fig. 1 Computer interface developed.

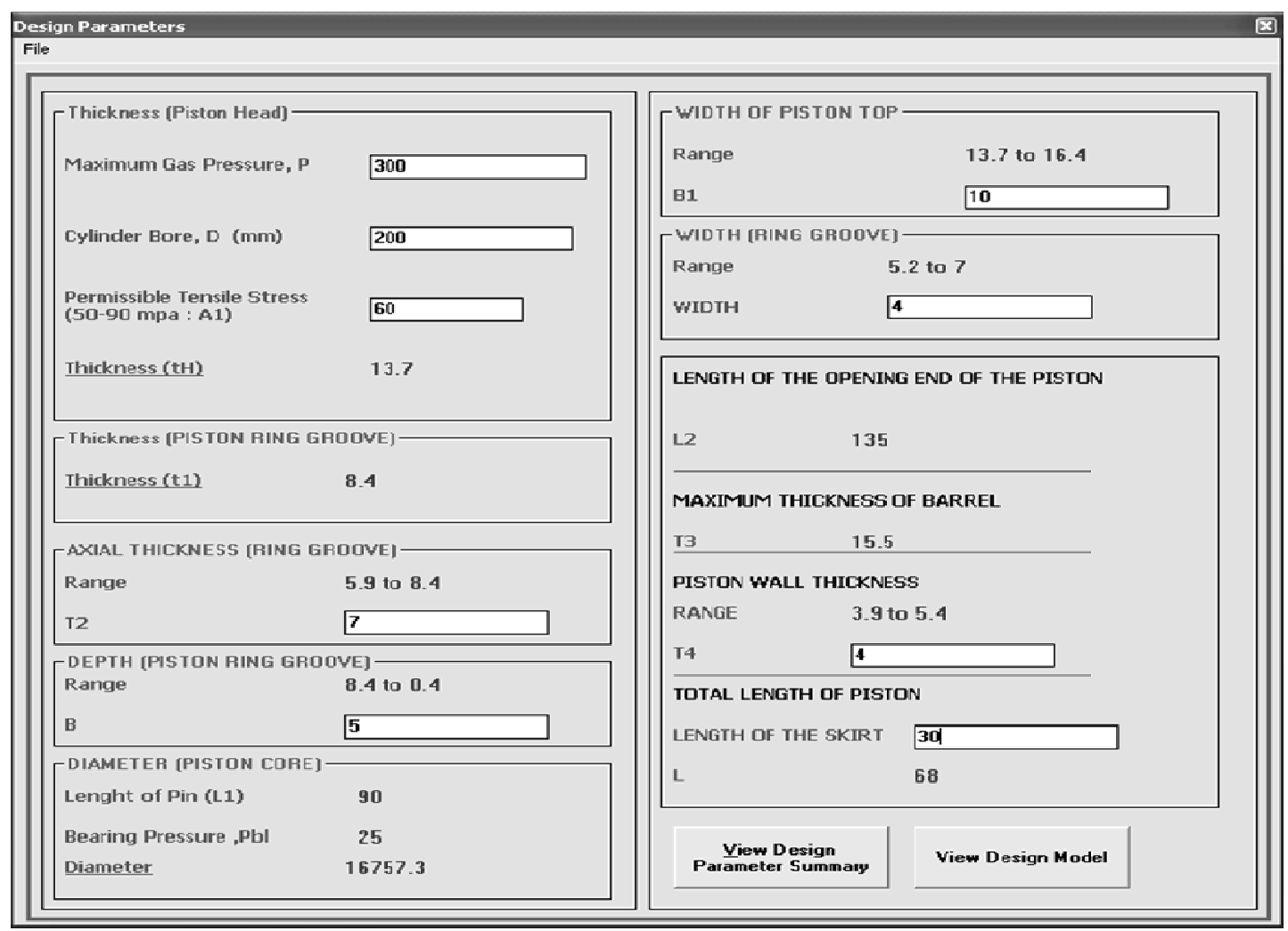

Fig. 2 Result interface for computer aided model for casting of aluminium developed. 


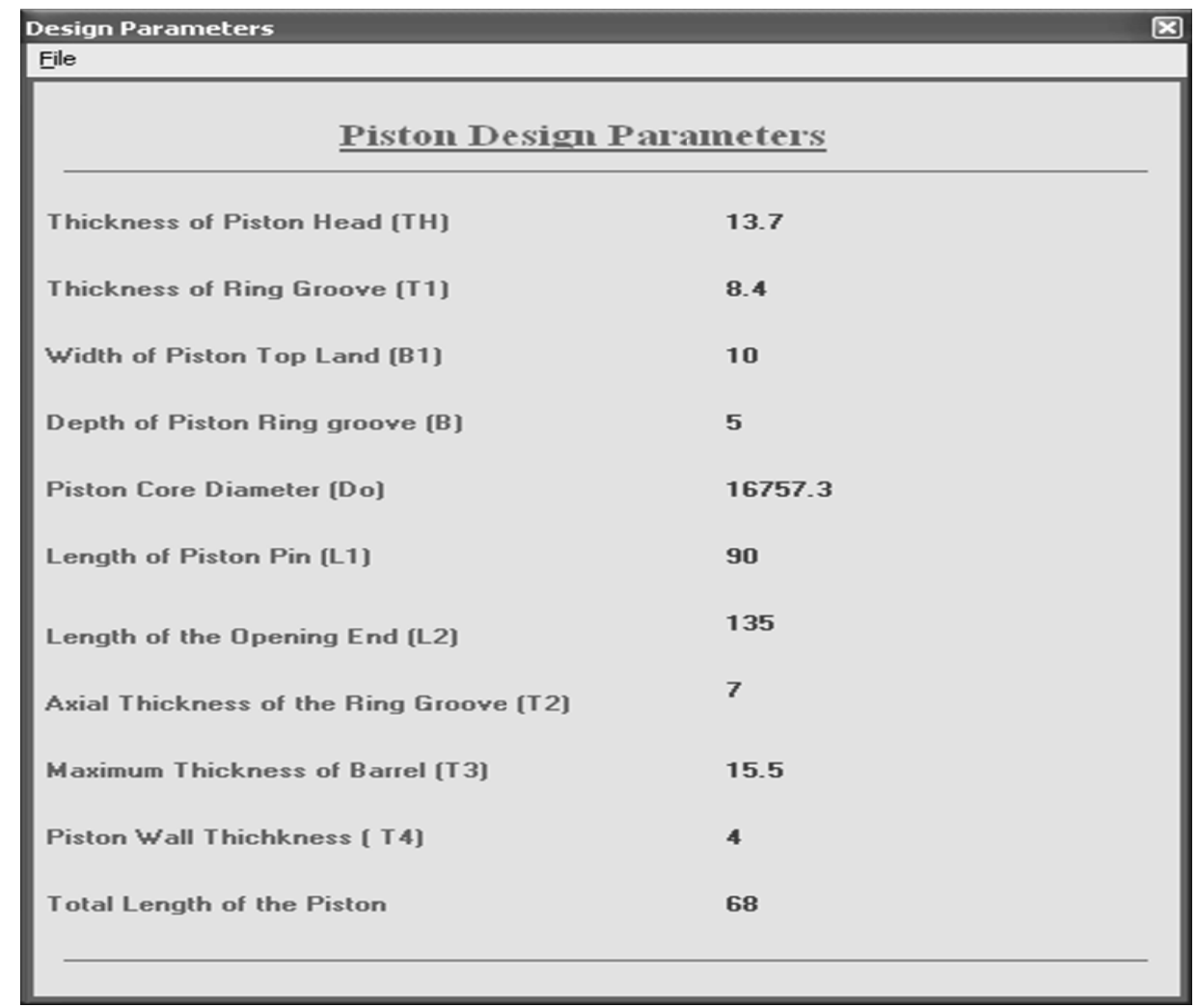

Fig. 3 Computer Result for the another set of Designed Parameters for piston.

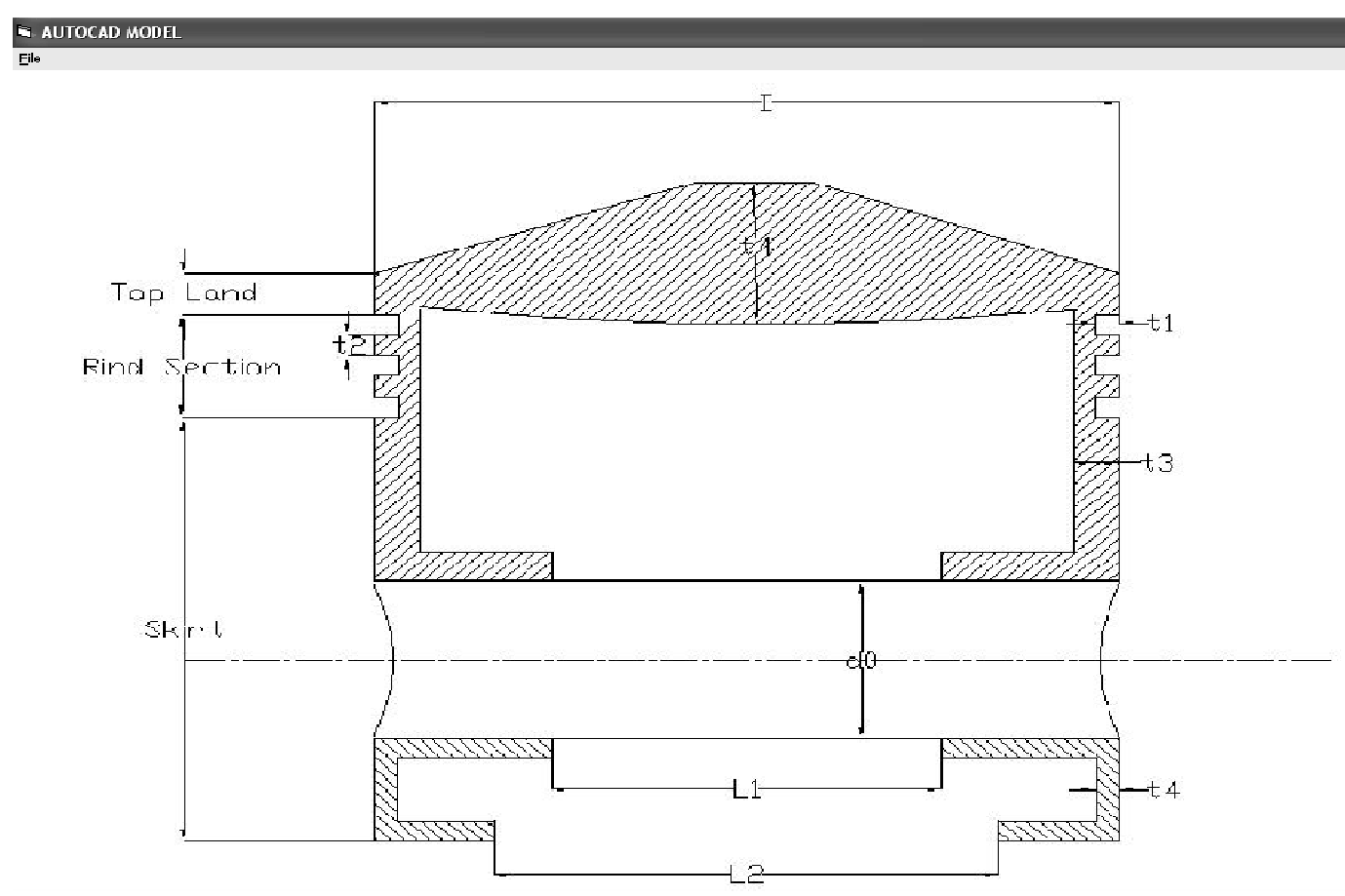

Fig. 4 Computer Aided Piston Model Developed.

Thickness of the ring groove (T1) was also calculated by using the formular and supplied data. Axial thickness of the ring groove ranges between $0.7 \mathrm{~T}, \mathrm{~T} 0, \mathrm{~T} 1$. Depth of the ring groove is $t_{1}$ to 0.4 . Piston pin core diameter was automatically calculated through the program, width of the piston top (B1) ranges from $1 \mathrm{TH}$ to $1.2 \mathrm{TH}$. 
Table 1 Piston design parameters.

\begin{tabular}{lll}
\hline S/N & Design parameters & Notations \\
\hline 01 & Thickness of piston head & TH \\
02 & Thickness of ring groove & T1 \\
03 & Width of piston top land & $\mathrm{B} 1$ \\
04 & Depth of piston ring groove & $\mathrm{B}$ \\
05 & Piston core diameter & $\mathrm{D}_{0}$ \\
06 & Length of piston pin & $\mathrm{L} 1$ \\
07 & Length of opening end & $\mathrm{L} 2$ \\
08 & Axial thickness of the ring groove & $\mathrm{T} 2$ \\
09 & Maximum thickness of barrel & $\mathrm{T} 3$ \\
10 & Piston wall thickness & $\mathrm{T} 4$ \\
11 & Total length of the piston & $\mathrm{L}$ \\
\hline
\end{tabular}

The design parameters considered for piston production is shown in Table 1.

The width of the ring ranges from 5.2 to 7 . Length of the opening end (L2) is $1_{1}+0.51_{1}$. Maximum thickness of the barrel $t_{3}$ is $0.03 \mathrm{D}+4.5$. Also the piston wall thickness (T4) value, which ranges from $0.25 \mathrm{t}_{3}$ to $0.35 \mathrm{t}_{3}$ was entered.

Fig. 2 presents the result interface of the Computer Aided model for casting of aluminium developed.With maximum gas presure of $300 \mathrm{MPa}$, cylinder Bore of $200 \mathrm{~mm}$ and permissible tensile stress of $60 \mathrm{Mpa}$. The model through the interface displayed the axial thickness (ring groove) to be $7 \mathrm{~mm}$, Depth of the piston ring groove to be $5 \mathrm{~mm}$, width of piston top to be $10 \mathrm{~mm}$, width of the piston groove to be $4 \mathrm{~mm}$, piston wall thickness to be $4 \mathrm{~mm}$ and total length of piston to be $30 \mathrm{~mm}$. Fig. 3 shows another set of designed parameters for piston. Fig. 4 is the computer aided piston developed.

\section{Conclusions}

Computer Aided Model for casting of aluminum using die-casting was developed. Case study of engine piston was used. A Computer program was written using visual basic language, which was used to develop a die-casting flow chart of casting of engine piston. The relevant data were used in the program. Data interface in the model allows basic design data to be entered, which eventually displayed the other necessary design parameters for the full design of aluminium piston to be cast.

The computer aided model for die casting of aluminium piston is found to be fast, saves time and produce design to specification.

\section{References}

[1] E.A. Anyebe, Combustion Engine and operations, automobile Technology Hand book, 2009, Vol. 2.

[2] R.K. Singal, International Combustion Engines, Kataria Books, New Delhi, India, 2010, pp. 43-46.

[3] E.P. Degarmo, J.T. Black, A. Ronald, Materias and Processes in Manufacturing, 9th ed., John Willy and Sons, London, 2003, pp. 89-91.

[4] J. Campbell, Casting, 2nd ed., Butterworth-Heineman, London, UK, 2003, pp. 56-58.

[5] B. Ravi, Metal Casting: Computer Aided Design and Analysis, 1st ed., Prentice-Hall New Delhi, India, 2005, pp. 23-26.

[6] B. Andresen, Die Casting Engineering, New York: Marcel Dekkar, 2005, pp. 56-59.

[7] S.B. Adejuyigbe, CAD/CAM for Manufacturing, Topfun Publication, Akure, Nigeria, 2002, pp. 65-69.

[8] M.P. Groover, Automation, Production and Computer Integrated Machine, Prentice-Hall New Delhi, India, 1992, pp. 34-39.

[9] J.T. Black, The Design of Factory with a Future, Prentice-Hall New Delhi, India, 2007. pp. 45-47.

[10] M.P. Groover, E.M Zimmer, CAD/CAM: Computer Aided Design and Manufacturing, Prentice Hall International in New Jersey, USA, 1984, pp. 78-80.

[11] C. Percy, L. Mett, Introduction to Computing, Macmillan Educational Ltd., London, 1990, pp. 78-82.

[12] C.S. Frech, Computer Science, DP Publication Limited, London, 1989, pp. 23-26.

[13] R.S. Klunmi, B.D. Gupta, A Textbook in Machine Design, Eurasia Publishing Horse, New Delhi, India, 2004, pp. 60-64.

[14] A.H.S. Al-shaab, R.M. Young, Design for injection moulding in a manufacturing environment, Journal of Design and Manufacture 5 (1) (1995) 45-54.

[15] D.H. Amestead, Manufacturing Process, John Willy and Sons, London, 1992, pp. 17-20. 